IRA-International Journal of Education \& Multidisciplinary Studies

ISSN 2455-2526; Vol.04, Issue 02 (2016)

Pg. no. 278-288

Institute of Research Advances

http://research-advances.org/index.php/IJEMS

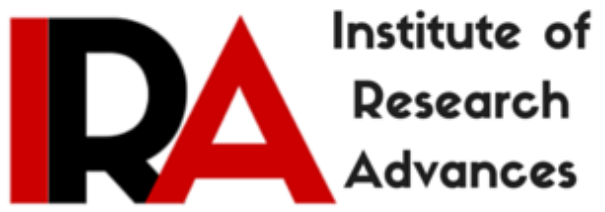

\title{
Comparative Study of Teaching Competency of Male and Female Trainees of Govt and Self Financed Colleges
}

\author{
${ }^{1}$ Priyanka Kartik \\ Assistant professor, DIET, Meerut, India. \\ ${ }^{2}$ Prof. Malvinder Ahuja \\ Retd. Prof. and Head, \\ Department of Education, \\ Panjab University, Chandigarh, India.
}

Type of Review: Peer Reviewed

DOI: http://dx.doi.org/10.21013/jems.v4.n2.p6

\section{How to cite this paper:}

Kartik, P., \& Ahuja, M. (2016). Comparative Study of Teaching Competency of Male and Female Trainees of Govt and Self Financed Colleges. IRA International Journal of Education and Multidisciplinary Studies (ISSN 2455-2526), 4(2), 278-288. doi:http://dx.doi.org/10.21013/jems.v4.n2.p6

(C) Institute of Research Advances

\section{(cc) BY-No}

This work is licensed under a Creative Commons Attribution-Non Commercial 4.0 International License subject to proper citation to the publication source of the work.

Disclaimer: The scholarly papers as reviewed and published by the Institute of Research Advances (IRA) are the views and opinions of their respective authors and are not the views or opinions of the IRA. The IRA disclaims of any harm or loss caused due to the published content to any party. 


\section{ABSTRACT}

This investigation was undertaken to study teaching competence of trainees gender wise and institution type wise. a sample of 100 B.T.C trainees were selected 50 each from DIET and one of the self financing college of Meerut district. Baroda teacher competency scale was used to observe pre instructional, instructional and post instructional skills of all these trainees (2010-2012 batch) during their final internship period. Analyses were done gender wise and institution wise. Means, SD and t-ratios were used to analyze data.

The findings revealed that;

- $\quad$ B.T.C. trainees of self financed institution were found to be more competent in the use of PreInstructional teaching skills.

- $\quad$ the trainees of self financed institution are superior to those of Govt. Institution with regard to their teaching competency on Instructional teaching skills.

- $\quad$ the trainees of self financed institution are superior to those of Govt. Institution with regard to their teaching competency on Instructional teaching skills.

- $\quad$ Male B.T.C. trainees were found to be more competent in the use of Pre-Instructional teaching skills as compared to their female counterparts.

- $\quad$ Male trainees were higher in teaching competency (instructional skills) as compared to female trainees of B.T.C. institutions.

- male B.T.C. trainees were superior to female B.T.C trainees with regard to their teaching competency on post- instructional skills.

Keywords; teaching competency, pre instructional, instructional, post-instructional skills Comparative study of teaching competency of male and female trainees of govt and self financed colleges

\section{Teaching competency}

The prime function of education is to draw out the potentialities of the child and develop them to meet the challenging situation in life. Proper education will keep the child to understand the society, and to adjust with the social environment for the development of the child. Teacher education programme is an effective means for making a teacher competent and efficient for this role. Of all the different factors which influence the quality of education and its contribution to national development, the quality, competence and character of teachers are undoubtedly the most significant. Nothing is more important than securing a sufficient supply of high quality recruits to the teaching profession, providing them with the best possible professional preparation and creating satisfactory conditions of work in which they can be fully effective.

Teacher education system is an important vehicle to improve the quality of school education. The revitalization and strengthening of the teacher education system is therefore a powerful means for the upliftment of education standards. It inculcates the necessary pedagogical skills, and competencies among the teachers and makes them professionally competent to meet the demands of the society. NCTE has formulated norms and standards for all teacher education courses i.e. pre-primary, primary, secondary, physical education and distance education courses.

The success of any educational process depends on teacher competency, teaching aptitude and attitude towards teaching and many more factors. Teaching competency is the competency of the teachers and their planning and preparation of lesson for teaching, class room management, knowledge of subject, interpersonal relationship, attitude towards the children, usage of teaching aids and time management during their teaching-learning. Teacher competencies are an outcome-based method for assessing teacher 
performance. They define key characteristics of successful teachers, without prescribing any specific curriculum or instructional practices. The competency characteristics are useful for teacher training, licensure and professional development.

There are two types of teacher education programmes, viz. In-service education and Pre-Service education. Four types of institutions govern all teacher education programmes.

- District institute of education and training(DIET)

- State institutes of education

- National council of educational research and training (NCERT).

- National institute of educational planning and administration

Out of these (DIET) are organized to schedule pre-services and in-service courses for elementary teachers and for personnel working in a non-formal and adult education at district level. B.T.C. is a preservice elementary teacher education programme, which is two year educational programme run in DIETs.

Two important phenomenon, of nineties namely, globalization of economy and establishment of National council for teacher education, set pace of privatization in field of teacher education in India, in general and in U.P. in particular. Till 1999, there was no self financed Teacher training college in U.P. All teacher training colleges of state were either Govt. managed or funded by state Govt. First time in 2010 six self financed institution for B.T.C course came in existence in Meerut district. Thereafter, year by year number of self financed teacher education institutions increased and this number reached to 25 during academic session on 2012-2014. The rationale of the self financing system of education lies on the development of education. But it has made the education system fully commercialized and profit oriented. Can such self financing colleges of education prepare the mind of the student towards their profession ? self financing system can be an innovative alternative of education system, if, it is quality oriented, rather than profit oriented. Is self financed system not a resource generating system? Does it only cater to the need of rich population? The Variability of self financing largely depends on their academic success. If, they succeed in maintaining the balance between academic excellence and social Justice, they may be in the vanguard of educational development in the near future and may move towards an independent system which is blend of global and national traditional and modern.

The major criticism against self financing colleges is that none of these institutions have facility for practice teaching, they lack proper organizational climate needed for skill development, and the trainees who receive their training in government institution and those in self finance institutions differ in their competencies. In such a scenario, it is need of the time to verify empirically the charges against self financed teacher education institutions. With this intention the researchers decided to undertake this research study.

Teaching competencies were viewed as a number of verbal and nonverbal teaching acts, like questioning, accepting pupil responses, rewarding, smiling, nodding to pupil response, movements, gestures, etc. These acts in particular combinations facilitate the achievement of objectives in terms of pupil growth. A set of related teaching acts or behaviors performed with an intention to facilitate pupil's learning can be called as a teaching skill.

Thus, the complex task of teaching is analyzed into limited, but well-defined components called 'teaching skills' that can be taught, practised, evaluated, predicted, controlled, and understood.The concept of teaching competency in India emerged from Competency Based Teacher Education (CBTE) programme (Passi and Sharma, 1981). 
There are several definitions and views expressed by various educationists on the meaning and evaluation of teaching competency. There are many approaches for identifying teaching skills. In India attempts have been made at the Centre of Advanced Study in Education (CASE), Baroda. They have been classified under three headings: pre-instructional skills, instructional skills, and Post-instructional skills. For the present investigation teaching competency has been considered as constituent of these three classes of teaching skills

REVIEW OF RELATED LITERATURE; A review of some of the researches relevant to the current study was done. Kaur (1988) found that in-service education and training of teachers had significantly contributed to the development of profession competency in Punjab and the process and structure variable had a positive bearing on the product variables. In-service education was useful in improving the skills of teachers and had a positive effect on their attitude towards teaching.Naseema (1994) studied teaching competency of secondary school physical science teachers in relation to their satisfaction of teaching the subject. Naseema and Ayshabi (1995) studied satisfaction as a predictor of perceived teaching competency. WONG Yu Fai, Tommy (1996) Studied Relationship between teacher competence and teachers' Inferences of students' Multidimensional self-concept. The results showed that the correlation between teacher competence and teachers' inferences of students' self-concept was high; suggesting that teacher' inferences of students' self-concept could be a part of teacher competence. Uday Koundinya (1998) studied Professional competency and its impact on professional pleasure. The finding revealed a high significant positive relationship between professional competency and professional pleasure. Lakshminarayan (2000) in his research study reveals that the Teaching Competency of teachers was influenced by motivation, attitude towards teaching and adjustment of primary teachers in both DPEP and Non DPEP districts. Parveen sharma (2006) examined teaching aptitude in relation to general teaching competency, professional teaching and academic achievement of B.Ed. pupil teachers. Findings showed that teaching aptitude of the pupil teachers was significantly highly correlated with their general teaching competence, professional interest and academic achievements and general teaching competence and professional interest of the pupil teacher significantly affect their teaching aptitude. F.L. Antony Gracious (2011) studied the relationship between creativity and teaching competency of prospective B.Ed. teachers. Findings shows there was no significant relationship between creativity and teaching competency of prospective B.Ed. teachers. Shri Kant Dwivedi (2012) examined Impact of pre service teacher education programme on teaching competence. It was found that B.Ed. Programme was effective in enhancing teaching competence of prospective teachers; it further added that B.Ed. Programme was equally effective in enhancing teaching competence of Both female and male prospective teachers. Viplove Passi (2012) studied teaching competency among schedule caste and non-schedule cast pupil teachers in relation to their emotional intelligence. The results showed that there was no significant difference between schedule caste and non-schedule cast teacher trainees on their emotional intelligence and teaching competency.

\section{OBJECTIVES OF THE STUDY}

The study has been designed to attain the following objectives:

1. To study the teaching competency (pre-instructional, Instructional, Post-Instructional skills) of B.T.C trainees from self finance institution and Government institution (DIET) of Meerut Dist.

2. To study the teaching competency (pre-instructional, Instructional, Post-Instructional skills) of Male and Female B.T.C trainees (pooled from self finance institution and Government institution (DIET) of Meerut Dist.)

\section{HYPOTHESIS OF THE STUDY}

Following Hypotheses were tested in the present research;

Ho.1: There is no significant difference in pre-instructional teaching skills of B.T.C. trainees studying in self finance institute and Government Institution DIET) of Meerut Dist.

Ho.2: There is no significant difference in Instructional teaching skills of B.T.C. Trainees 
studying in self finance institute and Government Institution (DIET) of Meerut Distt.

Ho.3: There is no significant difference in Post-Instructional teaching skills of B.T.C. trainees

studying in self finance institute and Government Institution (DIET) of Meerut Distt.

Ho.4: There is no significant difference in Pre-Instructional teaching skill of Male and female

B.T.C. Trainees.

Ho.5: There is no significant difference in Instructional teaching skill of Male and female

B.T.C. Trainees.

Ho.6: There is no significant difference in Post-Instructional teaching skill of Male and

Female B.T.C. Trainees.

\section{SAMPLE OF THE STUDY}

The sample for the present study was drown randomly from one self finance institution out of the six self finance institution and from government institution (DIET) of Meerut. Where B.T.C. training is running. 50 trainees was drawn randomly from one self finance institute and 50 B.T.C. trainees from Government Institution (DIET) of Meerut. A total of 100 trainees was selected for the study.

\section{The structure of sample;}

\begin{tabular}{|l|l|l|ll|l|}
\hline S.N. & $\begin{array}{l}\text { NAME OF THE } \\
\text { INSTITUTION }\end{array}$ & $\begin{array}{l}\text { TYPE OF } \\
\text { INSTITUTION }\end{array}$ & $\begin{array}{l}\text { NO. } \\
\text { STUDENTS } \\
\text { MALE } \\
\text { FEMALE }\end{array}$ & TOTAL \\
\hline $\mathbf{1 .}$ & $\begin{array}{l}\text { DIET; Chhota } \\
\text { Mawana, Meerut }\end{array}$ & $\begin{array}{l}\text { Government } \\
\text { institution for B.T.C }\end{array}$ & 25 & 50 \\
\hline $\mathbf{2 .}$ & $\begin{array}{l}\text { S.R. College of } \\
\text { Education Mawana } \\
\text { Road, Meerut }\end{array}$ & $\begin{array}{l}\text { Self } \\
\text { institution } \\
\text { for B.T.C }\end{array}$ & \multicolumn{2}{|l|}{25} & $\mathbf{5 0}$ \\
\hline & & TOTAL & $\mathbf{1 0 0}$ \\
\hline
\end{tabular}

\section{TOOL USED}

In the present study investigator used "General teaching competency scale", developed by B.K. Passi and M.S. Lalitha (1976).The GTCS is a 7-point rating scale measuring the use of skill by the teacher in the class-room corresponding to each item ranging from 1 for 'not at all ${ }^{1}$ to '7- for 'very much'. There are 21 items related to 21 teaching skills which encompass the entire teaching-learning process in the class-room and may be categorized as;

- Pre-Instructional Skills: which included Objectives of the lesson, content Selected, Organization of content selected, Audio-Visual Material,

- Instructional Skills: which included Introduction, Questions, Probing Questions, explanation, Illustration, Stimulus Variation, Reinforcement, Students Participation, Pacing lesson, Interaction, Use of Deliberate Silence and Nonverbal Cues and Using Black-Board.

- Post-Instructional Skills: included Closure, Home Assignment, Evaluation, Skill of Recognizing attending behavior, Class-Room Management.

Items are related to 16 major aspects of class-room teaching and are such that they are centered around teacher class-room behaviour in relation to Pupil behaviour. The reported inter-observer reliability coefficient's range from 0,85 to 0.91 . The scale has content validity since at every stage of its development, discussions were held with teachers and teacher educators with regard to the different teaching skills included and their behavioral components. The scale has factorial validly as well, Rama (1979)

Data Collection; B.T.C. training is basically a pre-service elementary teacher education programme which is of two years, divides in four semesters. Each semester is of 6 months. First three semesters are 
theoretically where as fourth semesters has three months theoretical \& 3 months internship (teaching practice is done in schools). Data were collected during internship period and teaching competency scale was individually administered by the investigator.

\section{ANALYSIS AND INTERPRETATION OF DATA}

To study the effect of teacher education training, on teaching competence of male and female trainees and B.T.C. trainees of Govt. and self finance institution data were collected during their internship period. The investigator observed teaching interactions of these trainees and recorded on Baroda teaching competence scale separately for each trainee. The observations were recorded separately for Pre-Instructional Skills, Instructional Skills and Post-Instructional Skills

The observation schedules were scored as per manual of the tools and means, SD' and t-ratios were calculated. The analyses of scores have been reported in two sections:

Section I: Deals with analyses of scores on Pre-Instructional, Instructional and post Instructional skills of trainees of Govt. and self financed institution.

Section II: Deals with analyses of scores on Pre-Instructional, Instructional and Post Instructional skills of male and female trainees.

\section{SECTION - I: COMPARISON OF TEACHING COMPETENCY OF TRAINEES FROM GOVT. AND SELF FINANCE INSTITUTIONS}

- PRE-INSTRUCTIONAL SKILLS OF TRAINEES OF GOVT. AND SELF FINANCE INSTITUTION

Analysis was done on scores of Pre-Instructional skills of B.T.C. trainees of DIET( govt) and SR College of education(private). Means, SD's and t-ratio were calculated on pooled score on Pre-instructional skills, and have been reported in the table 1

TABLE -1; Means and S.D's,t-ratio for scores of teaching competency (Pre instructional skills) of B.T.C trainees of government and self financed teacher Education Institutions.

\begin{tabular}{|c|c|c|c|c|c|}
\hline $\begin{array}{l}\text { Sl. } \\
\text { No }\end{array}$ & Name of Group & $\mathrm{N}$ & $\begin{array}{l}\text { Mean Competency } \\
\text { Score }\end{array}$ & S.D. & t-ratio \\
\hline 1 & $\begin{array}{l}\text { B.T.C. Trainees of Govt. } \\
\text { Institution (DIET) }\end{array}$ & 50 & 16.18 & 4.05 & \\
\hline 2 & $\begin{array}{l}\text { B.T.C. Trainees of self } \\
\text { Financed institution } \\
\text { College of Education) }\end{array}$ & 50 & 18.58 & 0.71 & $4.21 * *$ \\
\hline
\end{tabular}

Table 1 shows that the t-ratio for the difference in scores on pre-Instructional skills of B.T.C. Trainees belonging to Govt. and self financed teacher training institutions was found to be significant at the .01 level of confidence. This leads to the rejection of null hypotheses. 1 It may be inferred that two groups of B.T.C. Trainees teaching in Govt. Institutions and self financed institutions differ significantly in their teaching competency (pre- Instructional skills). An examination of means of scores of the two groups reveals that mean competency score on Pre-Instructional Skills of trainees belonging to self financed institution was higher than the mean competency score of trainees of Govt. institution. Therefore; it can be concluded that B.T.C. trainees of self financed institution were found to be more competent in the use of Pre- Instructional teaching skills. 
- INSTRUCTIONAL SKILLS OF TRAINEES FROM GOVT. AND SELF-FINANCE INSTITUTION

A Similar analysis was done on Instructional skills of trainees of DIET and SR College of education. Means, SDS and t-ratio were calculated on pooled score on instructional skills, and have been reported in the table -2

TABLE -2; Means and S.D's of scores for teaching competency (Instructional skills) of B.T.C trainees of government and self financed private teacher Education Institutions.

\begin{tabular}{|l|l|l|l|l|l|}
\hline $\begin{array}{l}\text { S1. } \\
\text { No }\end{array}$ & Name of Group N & $\begin{array}{l}\text { Mean Competency } \\
\text { Score }\end{array}$ & S.D. & t-ratio \\
\hline 1 & $\begin{array}{l}\text { B.T.C. Trainees of Govt. } \\
\text { Institution (DIET) }\end{array}$ & 50 & 43.60 & 12.89 & \multirow{2}{\mathbf{2.34}^{*}}{} \\
\hline 2 & $\begin{array}{l}\text { B.T.C. Trainees of self } \\
\text { Financed institution }\end{array}$ & 50 & 49.18 & 10.84 & \\
\hline
\end{tabular}

Table .2 shows Means, SD's and t-ratio for difference in scores of Teaching Competency on Instructional skills of B.T.C. Trainees belonging to Govt. and self financed teacher training institution. ' $t$ ' value 2.34 was found to be significant at the .05 level of confidence leading to the rejection of null hypotheses . 2 .It may be inferred that two groups of B.T.C. Trainees teaching in Govt. Institution and self financed institution differ significantly in their teaching competency on Instructional skills. Since mean competency score on Instructional Skills of trainees belonging to self financed institution was higher than the value for the teaching competency score in Govt. institution. It may therefore be concluded that the trainees of self financed institution are superior to those of Govt. Institution with regard to their teaching competency on Instructional teaching skills.

- POST - INSTRUCTIONAL SKILLS OF TRAINEES FROM GOVT. AND SELF FINANCE INSTITUTIONS

Means, SD's and t-ratio were calculated on pooled score of Post-Instructional skills of trainees of DIET and SR College of education and have been reported in the table -3

TABLE -3; Means and S.D's of scores for teaching competency (Post instructional skills) of

\begin{tabular}{|l|l|l|l|l|l|}
\hline $\begin{array}{l}\text { S1. } \\
\text { No }\end{array}$ & Name of Group Competency & S.D. & t-ratio \\
\hline 1 & $\begin{array}{l}\text { B.T.C. Trainees of Govt. } \\
\text { Institution (DIET) }\end{array}$ & 50 & 23.18 & 6.35 & \multirow{3}{\text{Sean}}{ Score } \\
\hline 2 & $\begin{array}{l}\text { B.T.C. Trainees of self } \\
\begin{array}{l}\text { Financed institution (SR } \\
\text { College of Education) }\end{array}\end{array}$ & 50 & 25.94 & 1.84 & \\
\hline
\end{tabular}

Table 3 shows that the t-ratio for the difference in scores on pre-Instructional skills of B.T.C. Trainees belonging to Govt. and self financed teacher training institutions was found to be significant at the .01 level of confidence. This leads to the rejection of null hypotheses. 3 . It may be inferred that two groups of B.T.C. Trainees teaching in Govt. Institution and self financed institution differ significantly in their teaching competency on Post-Instructional skills. Since the mean competency score on PostInstructional Skills of trainees belonging to self financed institution was higher than the value for the teaching competency score in Govt. institution, it may therefore be concluded that the trainees of self financed institution are superior to those of Govt. Institution with regard to their teaching competency on Instructional teaching skills. 


\section{SECTION - II: COMPARISON OF TEACHING COMPETENCY OF MALE AND FEMALE TRAINEES}

\section{- PRE-INSTRUCTIONAL SKILLS OF MALE AND FEMALE TRAINEES OF B.T.C} INSTITUTIONS

Analysis was done on Pre-Instructional skills of male and female trainees of DIET and SR College of education. Means, SD's and t-ratio were calculated on pooled score on pre-instructional skills, and have been reported in the table.4;

TABLE -4; Means and S.D's, t-ratio for scores of teaching competency (Pre instructional skills) of B.T.C male and female trainees pooled from govt and private institutions

\begin{tabular}{|l|l|l|l|l|l|}
\hline $\begin{array}{l}\text { Sl. } \\
\text { No }\end{array}$ & Name of Group & $\mathrm{N}$ & $\begin{array}{l}\text { Mean Competency } \\
\text { Score }\end{array}$ & S.D. & t-ratio \\
\hline 1 & $\begin{array}{l}\text { B.T.C. Trainees (Female) of } \\
\text { Govt. and self financed } \\
\text { Institution }\end{array}$ & 50 & 16.18 & 4.81 & $\mathbf{4 . 2 8 * *}$ \\
\hline 2 & $\begin{array}{l}\text { B.T.C. Trainees (Male) of } \\
\text { Govt. and self financed } \\
\text { Institution }\end{array}$ & 180 & 1.84 & \\
\hline
\end{tabular}

Considering table-4, the t-ratio for the difference in scores on pre-Instructional skills of Male and Female B.T.C. Trainees of Govt. and self financed teacher training institutions (when pooled together)was found to be significant at the .01 level of confidence. This leads to infer that two groups of B.T.C. Trainees, Male and Female differ significantly in their teaching competency (pre- Instructional skills). The null hypothesis-4 therefore stands rejected at the specified level. An examination of means of scores of the two groups reveals that mean competency score on Pre-Instructional Skills of Male trainees was higher than that of Female trainees. Therefore; it can be concluded that Male B.T.C. trainees were found to be more competent in the use of Pre- Instructional teaching skills as compared to their female counterparts.

- INSTRUCTIONAL SKILLS OF MALE AND FEMALE TRAINEES OF B.T.C

Means, SD's and t-ratio were calculated on pooled score on instructional skills of male and female trainees (taken together) and have been reported in the table.5;

TABLE -5; Means and S.D's, t-ratio for scores of teaching competency (instructional skills) of B.T.C male and female trainees pooled from govt and private institutions

\begin{tabular}{|l|l|l|l|l|l|}
\hline $\begin{array}{l}\text { Sl. } \\
\text { No }\end{array}$ & Name of Group Competency & S.D. & t-ratio \\
\hline 1 & $\begin{array}{l}\text { B.T.C. Trainees (Female) of } \\
\text { Govt. and self financed } \\
\text { Institution }\end{array}$ & 50 & 45.04 & 13.71 & \multirow{2}{\text{Sean}}{ Score } \\
\hline 2 & $\begin{array}{l}\text { B.T.C. Trainees (Male) of } \\
\text { Govt. and self financed } \\
\text { Institution }\end{array}$ & 50 & 47.68 & 10.64 & \\
\hline
\end{tabular}

Table 5 shows that t-ratio for difference in scores of teaching competency (instructional skills) of male and female trainees pooled together from Govt. and self financed teacher training institution was found to be significant at the .05 level of confidence. The significance of ' $t$ ' value leads to the rejection of 
null hypotheses 5 .It may be inferred that Male and female groups of B.T.C. Trainees Studying in Govt. institution and self financed institution differ significantly in their teaching competency on use of instructional skills. An examination of Mean scores of the two groups shows that Male trainees were higher in teaching competency (instructional skills) as compared to female trainees of B.T.C. institutions.

- POST INSTRUCTIONAL SKILLS OF MALE AND FEMALE TRAINEES OF B.T.C INSTITUTIONS

Means, SD's and t-ratio were calculated on pooled score on post-instructional skills, of male and female trainees and have been reported in the table.6

TABLE -6; Means and S.D's, t-ratio for scores of teaching competency (post-instructional skills) of B.T.C male and female trainees pooled from govt and private institutions

\begin{tabular}{|l|l|l|l|l|l|}
\hline $\begin{array}{l}\text { S1. } \\
\text { No }\end{array}$ & Name of Group & N & $\begin{array}{l}\text { Mean Competency } \\
\text { Score }\end{array}$ & S.D. & t-ratio \\
\hline 1 & $\begin{array}{l}\text { B.T.C. Trainees (Female) of } \\
\text { Govt. and self financed } \\
\text { Institution }\end{array}$ & 50 & 23.04 & 5.48 & \multirow{3}{*}{$\begin{array}{l}\text { 3.30** } \\
2\end{array}$} \\
\hline $\begin{array}{l}\text { B.T.C. Trainees (Male) of } \\
\text { Govt. and self financed } \\
\text { Institution }\end{array}$ & 50 & 26.08 & 3.50 & \\
\hline
\end{tabular}

Considering table 6, t- ratio for difference in scores of teaching competency on post-instructional skills of Male and female B.T.C. Trainees was found to be significant at the .01 level of confidence. It may be inferred that male and female groups of B.T.C. trainees pooled from Govt. institution and self financed institution differ significantly in their teaching competency on post-instructional skills. The null hypothesis-6 therefore stands rejected at the specified level. Observation of means of two groups led to conclude that male B.T.C. trainees were superior to female B.T.C trainees with regard to their teaching competency on post- instructional skills.

\section{CONCLUSIONS;}

- B.T.C. trainees of self financed institution were found to be more competent in the use of PreInstructional teaching skills.

- the trainees of self financed institution are superior to those of Govt. Institution with regard to their teaching competency on Instructional teaching skills.

- the trainees of self financed institution are superior to those of Govt. Institution with regard to their teaching competency on Instructional teaching skills.

- Male B.T.C. trainees were found to be more competent in the use of Pre- Instructional teaching skills as compared to their female counterparts.

- Male trainees were higher in teaching competency (instructional skills) as compared to female trainees of B.T.C. institutions.

- male B.T.C. trainees were superior to female B.T.C trainees with regard to their teaching competency on post- instructional skills.

\section{DISCUSSION OF RESULTS;}

The researchers cannot criticize finding of the study in the light of earlier research studies conducted in the area as we could not find even a single research study comparing competency in terms of teaching skills of B.T.C. Trainees studying in Govt. and self financed teacher training institutions. 
However, in absence of empirical evidence some general observations can be discussed regarding present findings.

It may be argued that students of Govt. institutions are selected through academic- merit base. It has been observed that candidates preparing for civil services and competitive services constitute the clientele of Govt run DIETs, or at least a good number of students are not aspiring for teaching profession. They are there simply to avail facilities of libraries. By doing so they prepare for competitions and as a by-product get a degree of B.T.C. they are bothered neither about their studies nor in the quality of their professionalism, or the degree. On the other hand, some students in self financed institution paid more than rupees, twenty two thousands, or forty four thousand and in some cases more than one Lac for admission in B.T.C. classes. These students are more serious about their course. Parents too, who invest rupees forty four thousand or twenty two thousand to one lac on their wards remind and monitor their studies more keenly in comparison with parents of Govt. institution who spent only four thousand four hundred as their course fee.

Another important fact which supports the results of current research is that self finance institutions are running B.T.C. course, (2010 B.T.C. Batch) for the first time. Hence self finance institutions are trying to do their best by adding better facilities i.e. institutional infrastructure, teaching staff, library facilities, etc. than Govt. institution's facilities. It means students of self financed institutions due to huge investment, high degree of motivation and constant monitoring of their parents exhibited superior teaching skills/ teaching competencies in Lesson planning, Introduction, Questioning, Probing Question, Explanation, Illustration, Stimulus Variation, Reinforcement, Students Participation, Pacing Lesson, Interaction, BlackBoard Writing, Closer, Home Assignment, Evaluating, Class Room Management, Total.

\section{REFERENCES;}

- Ahuja,M and anand Bhushan(2012). Educational technology.Patiala; Bawa Publishers

- Best, John W. (1993). Research in Education. New Delhi: Prentice Hall of India Pvt. Ltd.

- Dutt N.K. (1974). Psychological Foundations of Education, Delhi: Doaba House.

- Dwivedi, Shrikant (2012). Impact of Pre-Service teacher education Programme on teaching competence. Journal of Teacher Education and Research, volume-7, Number-1, Jun-2012, 96-109.

- Antony F.L., Gracious (2011). The relationship between creativity and teaching competency of prospective B.Ed. teachers. Turkish Journal of distance Education. TOJDE January 2011 ISSN 13026488 volume: 12 Number: 1 Notes for Editors-3.

- Kaur, (1998). In-Service education and training of teachers contribute to the development of professional competency in Punjab. Punjab University, Chandigarh.

- Kothari, C.R. (2000). Research Methodology. Wishwa Prakash Pvt. Ltd.

- Lakshminarayan, U. and Babu, G.V.S. (2000) A study of Indicators of teaching competence of teachers in DPEP and non-DPEP Schools. Indian Educational Abstract, 40 (1), January 2004.

- Naseema, (1994). Teaching Competency of Secondary School Physical Science teachers in relation to their satisfaction of teaching the subject. Ph.D. Education, University of Calicut.

- Passi, B.K. and Lalita, M.S. (1994). General teaching competence scale. Agra: National Psychological Corporation.Agra

- Sharma, Parveen (2006). A study of teaching aptitude in relation to General teaching competency, professional teaching and academic achievements of B.Ed. pupil teachers' Ph.D. Thesis, Jamia Millia Islamia, central University, New Delhi- 25.

- Raju, T.J., M.S. and Rao, S.N. (2011). Relationship between teacher efficacy and teaching competency among secondary school teachers. Educational Quist - An International Journal of Educational and applied social sciences. Volume : 2, Issue : 3 (2011) 
- Shanavaz, S. (2007). A Comprative study of teachers' competencies, attitude and their performance belonging to DPEP and Non DPEP district of Karnataka. Unpublished Ph.D. Thesis, University of Mysore, Mysore.

- Sharma, R.A. (2007). Psychology of Teaching learning Process. R.Lal Book Depot.L Meerut.

- Uday Koundinya, (1998). Professional competency of Teacher Educations and its Impact of Professional Pleasure: Research Paper presented in Regional seminar of NCERT at Mysore, 1998.

- Viplove Passi, (201). A Study of Teaching Competency among Scheduled caste and Non-Scheduled caste Pupil teachers in relation to their emotional intelligence. International Journal of Research volume: 1, No. 3 (2012).

- WONG Yu Fai, Tommy, (1996). Relationship between teacher Competence and teachers' Inferences of students, multidimensional self-concept. Unpublished Ph.d. thesis. 